\title{
Legal Policy for Management of Criminal Action of Narcotics in Low Education
}

\author{
Bayu Dwa Anugrah ${ }^{*}$ and Aryani Witasari**) \\ *) Student of Master of Law Program, Faculty of Law Universitas Islam Sultan Agung \\ email Email: bartholemewdkuma@gmail.com \\ ${ }^{* *}$ Faculty of Law Universitas Islam Sultan Agung
}

\begin{abstract}
.
The objectives of this research are: To know and analyze how legal handling of narcotics crime among low education.To find out and analyze obstacles and solutions prevention of narcotics crime among low education. The results of this study areWays to Overcome the Law on Narcotics Crime Among Low Education, among others: 1) Preventive, namely policies that see the root causes of the main causes of crime through a social approach, a situational approach and a community approach to eliminate the elements of potential interference (Correlative Criminogen Factors); 2) Preventive (prevention), namely to form a society that has resistance and immunity to drugs. Prevention is better than eradication; and 3) Repressive (repression), namely taking action against and eradicating drug abuse through legal channels and based on law, which is carried out by law enforcers or security forces assisted by the community. Internal obstacles are the lack of resources for sophisticated technology equipment to match the technological sophistication of drug network syndicates in distributing and producing drugs, while external obstacles that come from outside are the confusion of articles in the Narcotics Law regarding sanctions against victims of abusers, lack of participation and public participation as police intelligence to provide information and information in order to uncover and uncover cases of illicit traffic and narcotics abuse. Future efforts will be made to overcome obstacles in overcoming narcotics crime among low education. Drug Crime Unit personnel are given education or training on the use of technology so that they can use IT tools in order to detect narcotics offenders and networks; Narcotics Crime Unit personnel carry out vocational education in the field of combating narcotics crime. And the personnel of the Narcotics Crime Unit are required for investigators to continue their education to higher education so that their insight and understanding of the Narcotics Law can better understand so that they can carry out investigations into a more organized modus operandi.
\end{abstract}

Keywords: Legal Policy; Crime; Narcotics.

\section{Introduction}

The development of the times, both in technology and in science, also encourages the development of a crime that exists in the midst of society. The influence of increasingly sophisticated technological developments, cultural shifts and increasingly rampant physical development has made everyone selfish and materialistic. The development is expected to bring about changes for the sake of creating good things from the previous situation, but often ends with the 
emergence of new patterns of crime. ${ }^{1}$

As it is known, the Criminal Code (WvS) in effect in Indonesia so far has not formulated general criminal guidelines governing judge forgiveness. The formulation of the principle of rechterlijk pardon in the criminal guidelines is important because it is appropriate for the flexibility / elasticity and modification of punishment which comes from the values of religious wisdom. ${ }^{2}$

Crime which is currently the most frequently encountered problem in people's lives is the problem of abuse and trafficking of narcotics. Drug abuse and trafficking do not only involve adults but also involve teenagers and students. The problem of drug abuse and trafficking among adolescents and students is difficult to overcome, because the solution involves many factors and cooperation from all parties concerned such as the government, officials, society, mass media, families, teenagers themselves and other parties. Narcotics abuse occurs because the victim does not or does not understand what narcotics are so that irresponsible parties (dealers) can lie.

Lack of counseling and information in the community regarding the dangers of narcotics abuse, for this reason, counseling and educational actions must be planned, held and carried out effectively and intensively to the public and delivered by means or media appropriate to the community. ${ }^{3}$ Narcotics are substances or drugs derived from plants or non-plants, both synthetic and semisynthetic, which can cause a decrease or change in consciousness, loss of pain and can lead to dependence. ${ }^{4}$

Narcotics have penetrated all levels of Indonesian society, which are the targets not only for nightclubs, but also to residential areas, campuses and even to schools. The number of victims of narcotics abuse in Indonesia is increasing and is not limited to the wealthy community, given the high price of narcotics, but has also penetrated the low economic community.

Narcotics Abuse does not only reach the uneducated, but the abuse of narcotics has resided in all circles even to those who have been educated, starting from school children who incidentally are from the educated class, businessmen, even state officials and law enforcement officials were also caught in the Narcotics abuse case. It has been understood that many young Indonesians whose lives are stifling are tended to be controlled and controlled by Narcotics which should have enormous and positive benefits when used for medicinal purposes or in the field of knowledge, but by the current generation Narcotics is misused for various purposes. $^{5}$

\footnotetext{
${ }^{1}$ Irsan, Koesparmono. (1996). Kejahatan Dimensi Baru (Kejahatan Terorganisir), disampaikan panel Forum Kejahatan Teroganisir yang diselenggarakan oleh Badan Eksekutif Mahasiswa Universitas Gajah Mada, Yogyakarta.

2 Wahyuningsih, Sri Endah. (2018). Model Pengembangan Asas Hukum Pidana Dalam KUHP Berbasis Nilai-nilai Ketuhanan Yang Maha Esa, Semarang : Fastindo. p. 128.

3http://visiuniversal.blogspot.com/2014/03/masalah-penyalah-gunaannarkoba.html\#sthash.IcyVjnEi.dpuf, accessed on September 25, 2020, at 21.05 WIB

${ }^{4}$ Act No. 35 of 2009.

5 Suhasril, Makarao, and Mohammad Taufik. (2003). Tindak Pidana Narkotika. Jakarta: Ghalia Indonesia.p. 5.
} 
Legislative provisions regulating the issue of narcotics have been drafted and enforced, however, crimes related to narcotics cannot be mitigated. In many recent cases, many bandarbandar and dealers were caught and received heavy sanctions, but other actors seem to ignore them and are even more likely to expand their area of operation. ${ }^{6}$

The objectives of this research are: To know and analyze how legal handling of narcotics crime among low education.To find out and analyze obstacles and solutions prevention of narcotics crime among low education

\section{Research methods}

The approach method used is the sociological juridical approach, namely the approach method by looking at the facts in the field related to the problems that the writers raised and then connected with the applicable positive provisions. ${ }^{7}$ The research used is descriptive. "Descriptive research is research which is a problemsolving procedure investigated by describing or describing the current state of the subject and research object based on visible facts."8 The data used in this study are secondary data obtained through library research and primary data which are then analyzed qualitatively using law enforcement theory and rule of law theory.

\section{Results and Discussion}

\subsection{Ways of Handling the Law on Narcotics Crime Among Low Education}

In line with the provisions of Article 10 of the Criminal Code, the types of crimes in Act No. 35 of 2009 concerning Narcotics which are formulated are 4 (four) main types of crimes, namely death penalty, imprisonment, fines and imprisonment, so as long as they are not stipulated otherwise in Act No.35 of 2009 concerning Narcotics, then the criminal law applies to punishment in the Criminal Code, on the contrary if it is stipulated separately in Act No.35 of 2009, then the criminal rules in the Narcotics Law will apply.

In Act No. 35 of 2009 which deals with the perpetrator, both as a perpetrator and as a victim. When examined more deeply through the perspective of criminal politics, it can be found that these articles contain efforts to tackle crime, both penal and non-penal.

Efforts to overcome crime through penal channels are handling through criminal law. Roughly speaking, it can be said that efforts to combat crime through the penal route emphasize more on the "repressive" nature (suppression / eradication / suppression) after a crime has occurred. ${ }^{9}$

In its development, many narcotics abusers are neither traffickers nor involved in narcotics trafficking syndicates, often their motivation to use narcotics

\footnotetext{
${ }^{6}$ Sonarso, Siswantoro. (2004). Penegakan Hukum Dalam Kajian Sosiologis. Jakarta : Raja Grafindo Persada.p. 142.

7 Zainal Asikin, and Amirudin. (2004). Pengantar Metode Penelitian Hukum, Jakarta : Raja Grafindo. p. 133.

8 Abdulrahman, and Soerjono. (2003). Metode Penelitian Hukum. Jakarta : Rineka Cipta. p. 23.

9 Sri Endah Wahyuningsih, and Indah Lestari. Penegakan Hukum Pidana Terhadap Pengguna Narkoba Di Polda Jateng, Jurnal Hukum Khaira Ummah Vol. 12. No. 3 September 2017.
} 
is simply driven by curiosity, following in the footsteps of their friends, trying to find their existence in social relationships in the wrong way. People, especially the younger generation, who use narcotics are limited to trial and error then they become dependent, of course, must also be considered victims of narcotics illicit trafficking. Starting from trial and error even though the use of narcotics aims to create pleasure for the user, resulting in a psychological dependence. ${ }^{10}$ Even dependence on narcotics is one of the causes of illegal behavior. Of course, this condition also has to be treated differently from those who deliberately take advantage of the illicit trafficking of narcotics.

The surrounding community, on average, only took up high school education, besides that many of them dropped out of school. So that their understanding of the dangers of narcotics is not well known. Low education results in less comprehension and limited knowledge.

The policy to tackle the criminal act of narcotics abuse is a positive legal policy which is not merely the implementation of laws which can be carried out in a juridical normative and systematic manner. Apart from the normative juridical approach, criminal law policy also requires a factual juridical approach which can be in the form of a sociological, historical approach, and even requires a comprehensive approach from various disciplines. In this case, it can be understood that efforts to achieve prosperity through the aspect of prevention can be broadly divided into 2 (two) routes, namely: through the penal route (criminal law) and through the non-penal route (not / outside the criminal law). Efforts to control crime through penal channels are more burdensome for the repressive nature (suppression / eradication / crackdown) after the crime has occurred. Meanwhile, the non-penal route focuses more on preventive properties.

Furthermore, the prevention of narcotics crime is linked to criminal policies and social policies which are presented in the following chart:

${ }^{10}$ Sukarmi. (2012). Psikologi Hukum. Semarang : Unissula Press. p. 47. 


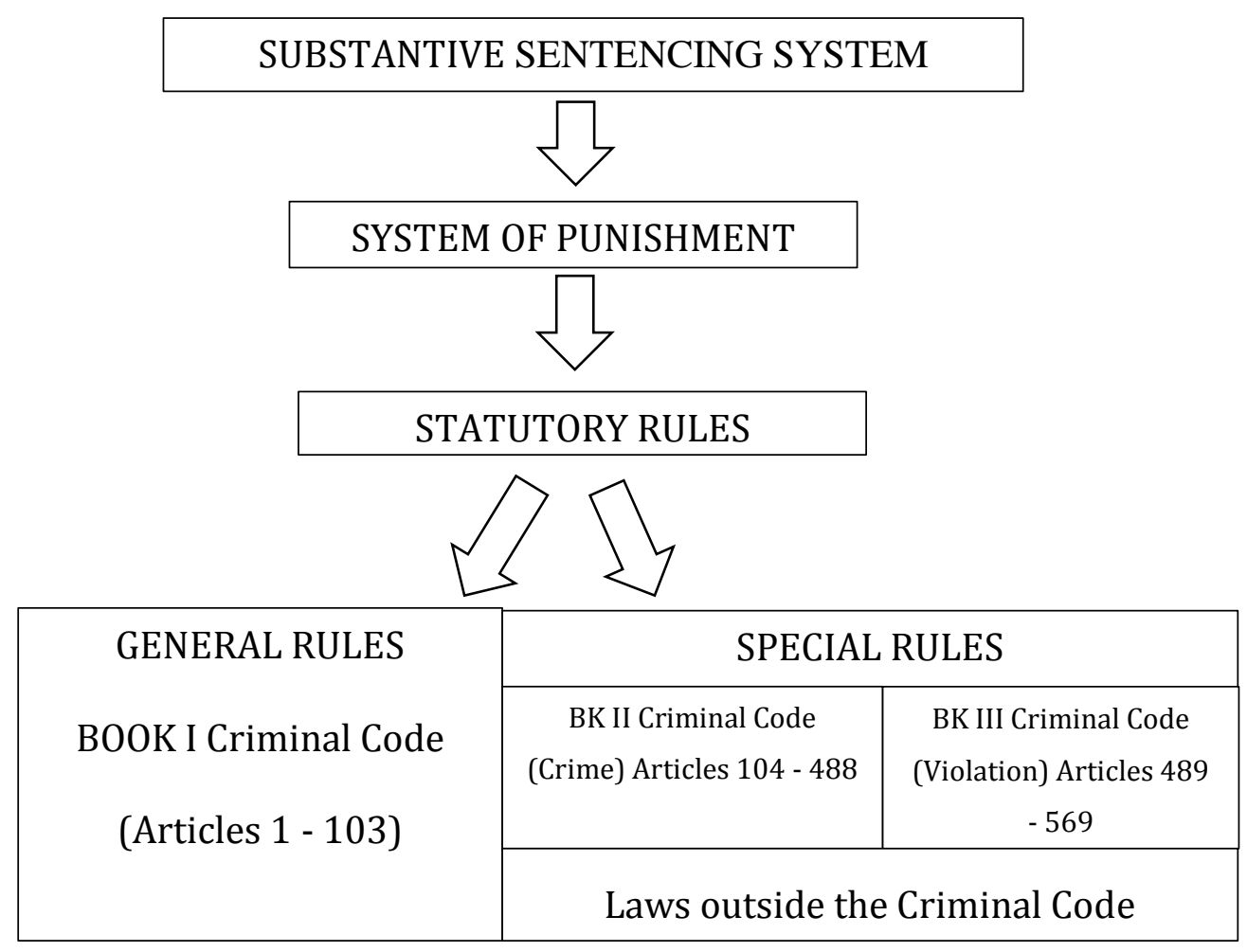

Ways to tackle the criminal law of narcotics among low education, including: 1) Preventive, namely a policy that looks at the root causes of the main causes of crime through a social approach, a situational approach and a community approach to eliminate the elements of Potential Disturbance (Correlative Criminogen Factors); 2) Preventive (prevention), namely to form a society that has resistance and immunity to drugs. Prevention is better than eradication .; and 3) Repressive (repression), namely taking action against and eradicating drug abuse through legal channels and based on law, which is carried out by law enforcers or security forces assisted by the community.

\subsection{Barriers and Solutions for the Prevention of Narcotics Crime among low education}

Narcotics abuse qualifies as a criminal offense in Act No. 35 of 2009 concerning Narcotics. The implementation of the criminal system against offenders of child abusers of nakotika puts a humanistic approach that takes into account the principle of criminal individualization in the use of criminal sanctions as a means of tackling crime. In essence, narcotics abusers are also victims who need medical assistance. The implementation of measures in the form of medical and social rehabilitation aims to improve the condition of narcotics abusers so that they are free from narcotics dependence so that they can return to society naturally. ${ }^{11}$

\footnotetext{
11Daris Warsito, and Dafit Supriyanto. Sistem Pemidanaan Terhadap Pelaku Tindak Pidana Penyalahguna Narkotika, Jurnal Daulat Hukum Vol. 1. No. 1 March 2018 ISSN: 2614-560X, Unissula.
} 
Efforts to overcome crime through penal channels are handling through criminal law. Roughly speaking, it can be said that efforts to combat crime through the penal route emphasize more on the "repressive" nature (suppression / eradication / suppression) after a crime has occurred. ${ }^{12}$

The eradication of the crime of narcotics involves all nations in the world, but it turns out that the level of illicit narcotics trafficking is increasingly high and rampant. Several indications show that narcotics crimes are extraordinary crimes. The definition is as a crime which has a huge and multi-dimensional impact on the social, cultural, economic and political aspects as well as the negative impact caused by this crime. For this reason, extraordinary punishment is very necessary for the extraordinary types of crimes that have occurred in all nations of the world as transnational crimes. ${ }^{13}$

Drug abuse is still a chronic problem that afflicts Indonesia, cases of methamphetamine distribution and the many arrests of international drug dealers in recent years are proof that Indonesia is in a state of drug emergency. The Indonesian government puts forward the role of the Police and the National Narcotics Agency (BNN) in order to prevent and eradicate drug trafficking in Indonesia. The efforts to prevent and eradicate drugs are carried out in three stages, namely first, Preemptive, namely prevention efforts carried out early. Second, prevention, namely efforts that are strategic in nature and constitute medium and long-term action plans, but must be viewed as urgent actions to be implemented immediately. ${ }^{14}$

In implementing efforts to tackle the crime of narcotics abuse among low education students, there are several obstacles, some of which come from internal and some come from external. Internal obstacles are the lack of resources for sophisticated technology equipment to match the technological sophistication of drug network syndicates in distributing and producing drugs, while external obstacles that come from outside are the confusion of articles in the Narcotics Law regarding sanctions against victims of abusers, lack of participation and public participation as police intelligence to provide information and information in order to uncover and uncover cases of illicit traffic and narcotics abuse.

Future efforts are being made to overcome obstacles in overcoming narcotics crime among low education. Drug Crime Unit personnel are given education or training on the use of technology so that they can use IT tools to detect narcotics offenders and networks; Narcotics Crime Unit personnel carry out vocational education in the field of combating narcotics crime. And the personnel of the Narcotics Crime Unit are required for investigators to continue their education to higher education so that their insight and understanding of the Narcotics Law can better understand so that they can carry out investigations into a more organized modus operandi.

\footnotetext{
${ }^{12}$ Sri Endah Wahyuningsih, and Indah Lestari. Penegakan Hukum Pidana Terhadap Pengguna Narkoba Di Polda Jateng, Jurnal Hukum Khaira Ummah Vol. 12. No. 3 September 2017, Unissula.

13 Kadarmanta, A. Kejahatan narkotika: Extraordinary crime dan extraordinary punishment, http://kejahatan-narkotika-extraordinary-crime.html, accessed on November 21, 2020.

14 Hariyanto, Bayu Puji. Pencegahan Dan Pemberantasan Peredaran Narkoba Di Indonesia, Jurnal Daulat Hukum Vol. 1. No. 1 March 2018 ISSN: 2614-560X.
} 
According to the author, Obstacles and Solutions for Narcotics Crime in lower education are analyzed from a point of view using law enforcement theory that The norms to be enforced include the meaning of formal and material law. Formal law is only concerned with written statutory regulations, while material law includes all definitions of the values of justice that live in society. It is intended to emphasize that the laws that must be upheld are not in essence the norms of the rules themselves, but the values of justice contained therein. Indeed, there is a doctrine that distinguishes between the duties of judges in the process of proof in criminal and civil cases. In civil cases it is sufficient for judges to find mere formal truths, whereas in criminal cases, then judges are required to seek and find material truths concerning the values of justice that must be realized in criminal justice.

\section{Closing}

\subsection{Conclusion}

Based on the results of research and discussion, the following conclusions and suggestions can be drawn:

Ways to tackle the criminal law of narcotics among low education, including: 1) Preventive, namely a policy that looks at the root causes of the main causes of crime through a social approach, a situational approach and a community approach to eliminate the elements of Potential Disturbance (Correlative Criminogen Factors); 2) Preventive (prevention), namely to form a society that has resistance and immunity to drugs. Prevention is better than eradication.; and 3) Repressive (repression), namely taking action against and eradicating drug abuse through legal channels and based on the law, which is carried out by law enforcers or security forces assisted by the community.

Barriers and Solutions for the Prevention of Narcotics Crime among low education. Internal obstacles are the lack of resources for sophisticated technology equipment to match the technological sophistication of drug network syndicates in distributing and producing drugs, while external obstacles that come from outside are the confusion of articles in the Narcotics Law regarding sanctions against victims of abusers, lack of participation and public participation as police intelligence to provide information and information in order to uncover and uncover cases of illicit traffic and narcotics abuse.

Future efforts are being made to overcome obstacles in overcoming narcotics crime among low education. Drug Crime Unit personnel are given education or training on the use of technology so that they can use IT tools to detect narcotics offenders and networks; Narcotics Crime Unit personnel carry out vocational education in the field of combating narcotics crime. And the personnel of the Narcotics Crime Unit are required for investigators to continue their education to higher education so that their insight and understanding of the Narcotics Law can better understand so that they can carry out investigations into a more organized modus operandi. 


\subsection{Suggestion}

In the application of Act No. 35 of 2009 concerning Narcotics in order to be more effective, there needs to be coordinated action between parties or agencies such as between the police and the National Narcotics Agency, the Ministry of Transportation, the Ministry of Education and Culture, the Ministry of Religion, educational institutions, social organizations and others.

Young people and girls are the young generation as the nation's successor candidates, therefore, do not get trapped in narcotics abuse, therefore: Providing understanding of religion through noble moral values and moral fostering to the younger generation starting from the family, because religion and morals are the initial strongholds that can protect families from damage and destruction including from the dangers of narcotics; Providing a clear understanding that narcotics is a very dangerous and destructive item, so that the misuse of narcotics is an act or a criminal act that can be punished with severe punishment and will be shunned by the family and society; It is necessary to provide understanding and understanding that once trying narcotics will continue to become addictive which then increases into dependence; It is necessary to provide understanding and understanding that narcotics abuse will distance itself from family, friends, and social life; It is necessary to provide understanding and understanding of the risks of narcotics abuse that will have a fatal impact on oneself and others.

\section{References}

\section{Journals:}

[1] Daris Warsito, and Dafit Supriyanto. Sistem Pemidanaan Terhadap Pelaku Tindak Pidana Penyalahguna Narkotika, Jurnal Daulat Hukum Vol. 1. No. 1 March 2018 ISSN: 2614-560X, Unissula.

[2] Hariyanto, Bayu Puji. Pencegahan Dan Pemberantasan Peredaran Narkoba Di Indonesia, Jurnal Daulat Hukum Vol. 1. No. 1 March 2018 ISSN: 2614-560X.

[3] Indah Lestari, Sri Endah Wahyuningsih, Criminal Law Enforcement Against Drug Users at the Central Java Regional Police, Khaira Ummah Legal Journal Vol. 12. No. 3 September 2017, Unissula

[4] Irsan, Koesparmono. (1996). Kejahatan Dimensi Baru (Kejahatan Terorganisir), disampaikan panel Forum Kejahatan Teroganisir yang diselenggarakan oleh Badan Eksekutif Mahasiswa Universitas Gajah Mada, Yogyakarta.

[5] Sri Endah Wahyuningsih, and Indah Lestari. Penegakan Hukum Pidana Terhadap Pengguna Narkoba Di Polda Jateng, Jurnal Hukum Khaira Ummah Vol. 12. No. 3 September 2017, Unissula.

\section{Books:}

[1] Abdulrahman, and Soerjono. (2003). Metode Penelitian Hukum. Jakarta : Rineka Cipta.

[2] Sonarso, Siswantoro. (2004). Penegakan Hukum Dalam Kajian Sosiologis. Jakarta : Raja Grafindo Persada. 
[3] Suhasril, Makarao, and Mohammad Taufik. (2003). Tindak Pidana Narkotika. Jakarta: Ghalia Indonesia.

[4] Sukarmi. (2012). Psikologi Hukum. Semarang: Unissula Press.

\section{Internet}

[1] http://visiuniversal.blogspot.com/2014/03/masalah-penyalah-gunaannarkoba.html\#sthash.IcyVjnEi.dpuf, accessed on September 25, 2020, at 21.05 WIB.

[2] Kadarmanta, A. Kejahatan narkotika: Extraordinary crime dan extraordinary punishment, http://kejahatan-narkotika-extraordinary-crime.html, accessed on November 21, 2020. 